\title{
Using Living Labs to Explore Needs and Solutions for Older Adults With Dementia: Scoping Review
}

Henk Verloo ${ }^{1,2}, \mathrm{PhD}$; Adrien Lorette ${ }^{2}, \mathrm{MD}$; Joëlle Rosselet Amoussou ${ }^{3}, \mathrm{MSc}$; Estelle Gillès de Pélichy ${ }^{4}$, MD; Alcina Matos Queirós ${ }^{5,6}$, MSc; Armin von Gunten ${ }^{7}$, MD; Elodie Perruchoud ${ }^{1}$, MSc

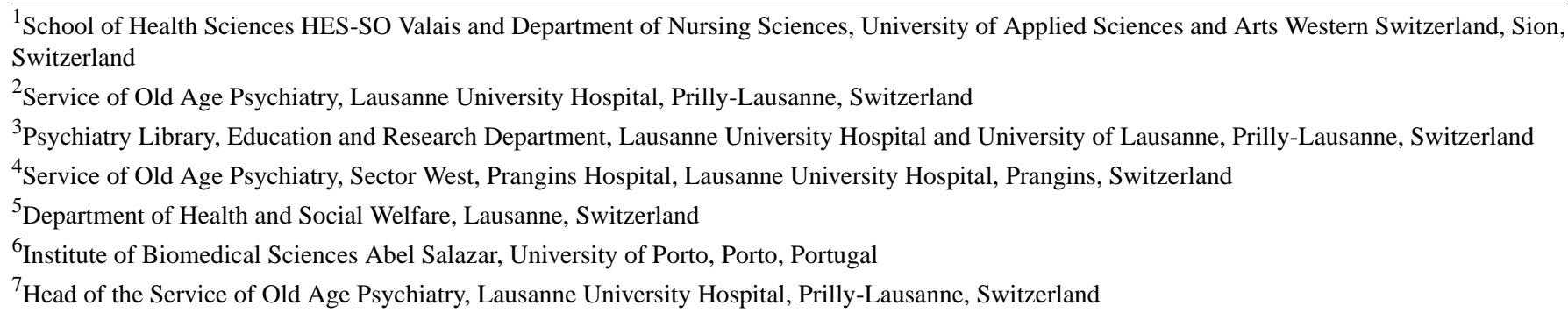

Corresponding Author:

Henk Verloo, PhD

School of Health Sciences HES-SO Valais and Department of Nursing Sciences

University of Applied Sciences and Arts Western Switzerland

Chemin de l'Agasse 5

Sion, 1950

Switzerland

Phone: 41787698990

Fax: 41216068400

Email: henk.verloo@hevs.ch

\section{Abstract}

Background: Numerous living labs have established a new approach for studying the health, independent living, and well-being of older adults with dementia. Living labs interact with a broad set of stakeholders, including students, academic institutions, private companies, health care organizations, and patient representative bodies and even with other living labs. Hence, it is crucial to identify the types of cocreations that should be attempted and how they can be facilitated through living labs.

Objective: This study aims to scope publications that examine all types of living lab activities, exploring the needs and expectations of older adults with dementia and seeking solutions, whether they live in the community or long-term health care facilities (LTHFs).

Methods: This scoping review was reported according to the PRISMA (Preferred Reporting Items for Systematic Reviews and Meta-analyses) recommendations for the extension of scoping reviews. We searched six bibliographic databases for publications up to March 2020, and a forward-backward citation chasing was performed. Additional searches were conducted using Google Scholar. The quality of the selected papers was assessed.

Results: Of the 5609 articles identified, we read $58(1.03 \%)$ articles and retained $12(0.21 \%)$ articles for inclusion and final analysis. All 12 articles presented an innovative product, developed in 4 main living labs, to assist older adults with cognitive disorders or dementia living in the community or LTHFs. The objectives of these studies were to optimize health, quality of life, independent living, home care, and safety of older adults with cognitive disorders or dementia, as well as to support professional and family caregivers or reduce their burdens. The overall methodological quality of the studies ranged from poor to moderate.

Conclusions: This scoping review identified several living labs playing a pivotal role in research aimed at older adults with dementia living in the community or LTHFs. However, it also revealed that living labs should conduct more better-quality interventional research to prove the effectiveness of their technological products or service solutions.

International Registered Report Identifier (IRRID): RR2-10.2147/SHTT.S233130

(JMIR Aging 2021;4(3):e29031) doi: $\underline{10.2196 / 29031}$ 


\section{KEYWORDS}

living lab; aged; dementia; cognitive dysfunction; long-term care; primary health care; technology; mobile phone

\section{Introduction}

\section{Background}

The world's population of people aged $>65$ years is growing rapidly. In Europe, their proportion has increased from $14 \%$ in 2010 to $28 \%$ in 2020 [1]. According to the World Health Organization, approximately $20 \%$ of people aged $\geq 65$ years have difficulties performing some of the activities of daily living (ADL) or instrumental ADL, often due to reduced mobility, weakened muscular strength, and disorders linked to cognitive disorders [2]. Innovative technologies or services are being used more frequently to provide responses to health problems, particularly for those affected by dementia [3]. In parallel, health care professionals and individual citizens want to participate in relevant, innovative, and implementable solutions that challenge the mainstream conceptions of the targets of health innovation [4]. Recent years have seen numerous studies reporting the advantages of adopting user-centered design approaches for developing innovative solutions. These approaches question users about their needs or observe their behavior with respect to a product, technology, or piece of equipment [5]. More recently, design research has evolved from a user-centered approach, wherein users are considered experimental subjects, to a more participatory approach, wherein users are considered partners [6]. This perspective points to the utility of design methods oriented toward increasing user and stakeholder participation, whether they are nonspecialists or professionals $[7,8]$. The emergence of living lab (LL) approaches has enabled researchers to go beyond the user-centered vision by adopting a user-driven perspective supported by other stakeholders [6]. LLs can turn the main beneficiary of a problem's resolution into an actor with a key role in a scientific process [9].

There are many different definitions of an LL depending on the domain and the author's research field; therefore, a widely recognized definition is lacking [10]. Depending on the definition, LLs are considered as a methodology for user-driven innovation; a user-driven, open-innovation ecosystem; a focus group involving users and stakeholders; or even an experiment in the environment [6]. This scoping review retained the definition presented by Bergvall-Kåreborn and Ståhlbröst [11]: "a living lab is a user-centric innovation environment built on every-day practice and research, with an approach that facilitates user influence in open and distributed innovation processes engaging all relevant partners in real-life contexts, aiming to create sustainable values." With regard to older adults with dementia in different health care settings, Bergvall-Kåreborn and Ståhlbröst [11] also stated that an LL could be "a pragmatic research environment, which openly engages all relevant partners with an emphasis on improving the real-life care of people living with dementia through the use of economically viable and sustainable innovation" [12]. LLs can be viewed as settings for open innovation that provide collaborative platforms for research, development, and experimentation in real-life contexts using specific methodologies and tools [13]. Følstad [14] described nine characteristics of LLs, four of which are discovery, evaluation, familiar contexts, and a focus on the medium to long term. The other five contribute to the variety of LLs as they may or may not be displayed: the investigation of the context, active roles for the users, technical testing, real-world contexts, and multiple settings [14]. In the context of ever-increasing worldwide economic competition, it is becoming necessary for industries and companies to innovate incessantly. However, it has been estimated that $70 \%$ of the innovative products and services they develop cannot find a market because they do not meet the real-world user needs [15]. Given that LL solutions are developed under conditions that are designed to be closer to reality and that they can produce more effective solutions to the needs of end users, LLs represent a considerable advantage in many industrial and economic sectors [16]. By using LL platforms and methodologies, companies and health care institutions can reach beyond their own boundaries, follow an open-innovation model [17], and integrate outsiders into the cocreation of products [18], experiences, designs, quality implementation strategies, and service development [17]. LLs often act as intermediaries or innovation facilitators for the cocreation process by providing structure and governance $[19,20]$. The key components of LLs include information and communication technology (ICT), management, stakeholders, research, and methods of cocreation and product testing [12]. The ICT and infrastructure component reflects the role that new and existing ICT can play in facilitating new means of cooperating and cocreating innovations among stakeholders. The research symbolizes the collective learning and thinking that occurs in an LL and should contribute to both theory and practice. Technological research partners can also provide direct access to the panels of older adult testers of new products, which can benefit the development of technological innovation with regard to criteria such as ease of use [12].

\section{LLs for Older Adults With Dementia}

Dementia is a progressive, disabling, chronic disease affecting $5 \%$ of all people aged $>65$ years and $>40 \%$ of people aged $>90$ years [21]. Older adults with dementia need a great deal of support and assistance, and this need increases with the progression of the disease [22]. Nevertheless, most older adults prefer to live in their own homes for as long as possible, even if they risk falls, are disabled, or are physically and mentally impaired [23]. Although this decreases the pressure on nursing homes and other long-term health care facilities (LTHFs), it increases pressure on both informal family caregivers and community health professionals [24]. Some research and development has been conducted on cognitive prosthetic devices; however, there are few relevant tools, solutions, or technologies specifically for people with dementia [25].

To the best of our knowledge, there are no clear overviews of the research conducted by LLs either using modern assistive technology specifically designed for older adults with cognitive impairment or dementia or based on their observed and expressed needs. Numerous studies have addressed the areas of concern for aging populations in general rather than specifically for those with dementia [26]. Some studies have 
reported on the use of general memory aids that can be used by those affected by memory problems and other cognitive impairments [27]. These studies were often conducted in traditional laboratory settings and did not include older adults in their natural environments. Although laboratory studies are easier to control, their ecological validity is limited [28]. Considering the needs of older adults with dementia in conjunction with relevant technologies has led to the identification of potentially innovative solutions for cognitive reinforcement. The increasing drive to develop innovative, cost-effective dementia care strategies will only work effectively if innovative technologies meet the real needs of people living with dementia. These processes are often only discussed with their informal or professional caregivers, yet there is evidence that people with dementia are very capable of participating [29]. Involving them in the studies of their day-to-day life is challenging; however, because of their impaired cognitive abilities, studies that do not include them will face difficulty demonstrating the potential effects of implementation in real life [29]. LLs can involve people in their natural environments, thus providing more environmentally valid evaluations in the context of innovations for dementia [30].

The literature already contains attempts to explain and analyze the effects of LLs on technology and communication [31,32]. However, the many different and separate needs of older adults with dementia and their respective solutions remain underresearched [33]. This study aims to scope publications examining all the types of LL activities, exploring the needs and expectations of older adults with dementia, and suggesting solutions for them, whether they live in the community or in LTHFs. The following research question defined our search: "What does the literature say about living labs whose activities are dedicated to older adults with dementia living in the community or in LTHFs?" The overall outcomes of this scoping review will provide useful insights into existing activities and identify any remaining gaps in the services provided and the research conducted by LLs [34]. It will summarize knowledge on the contributions of (old age) LLs exploring needs, testing technology, and applying user-based approaches for improving the lives of older adults with dementia living in the community and LTHFs. The specific objectives are identifying LL activities linked to older adults with dementia; describing the fields of action of LLs dedicated to older adults with dementia and the types of research they conduct, investigating the technologies cocreated in LLs to improve the independence and quality of life of older adults with dementia, considering the impact of such solutions with regard to how effectively they reduce burdens on informal and formal caregivers, and addressing how LLs involve various stakeholders in identifying needs and finding solutions for older adults with dementia so that they can live more independently and with a better quality of life.

\section{Methods}

\section{Overview}

This scoping review was based on the guidelines published by Tricco et al [35]. The research protocol for this scoping review has been documented elsewhere [34]. Studies were included if they provided a description of the cocreation process; research methodology or design; the stakeholders involved; the impact or effects on independence or quality of life; or the impact or effects on health status, as defined by the authors. Studies were included if they were conducted within LLs or by researchers and managers (eg, health care professionals, ICT experts, and engineers) attached to an LL and working with older adults with dementia living in the community or LTHFs.

\section{Outcomes}

The primary outcomes were information on the nature, number, and assessment of studies conducted with older adults with dementia performed by or in collaboration with LLs. Secondary outcomes were information on the documentation produced by different types of LLs, their objectives, the location of their interventions, and the types and methods of cocreation used for developing technologies and services for older adults and other stakeholders.

\section{Search Strategy}

The search was conducted by a medical librarian (JRA) in March 2020. Six bibliographic databases-were searched-Embase.com, MEDLINE Ovid, PubMed (not MEDLINE[sb]), CINAHL EBSCO, APA PsycINFO Ovid, and the Web of Science Core Collection-with no language or date restrictions. The detailed search strategies are available in Multimedia Appendix 1. Additional searches were conducted in Google Scholar in French and English, and the Journal of Engineering and Technology Management (ISSN 0923-4748), Technology Innovation Management Review (ISSN 1927-0321), and the Journal for Virtual Organization and Networks (ISSN 1741-5225) were manually searched. A forward citation search based on key articles was conducted in the Web of Science Core Collection and Google Scholar in January 2021. Two members of the research team (HV and EP) performed reference screening and reviewed the bibliographies of the selected studies.

\section{Study Screening, Data Collection Process, and Data Items}

Two reviewers (HV and EP) independently reviewed the abstracts and full text papers. In cases of disagreement, a consensus was reached through discussions and consultations with the coauthors. The research team developed Microsoft Excel spreadsheets to tabulate data on the studies and interventions and on their study quality assessments. The following information was extracted from each relevant study included and put into an appropriate usable form: (1) study authors, year of publication, and country where the study was conducted; (2) study characteristics (including research questions, study setting and design, sample size, instruments used, duration of follow-up, and stakeholders involved); (3) participants' characteristics (including age, sex, health status, and place of living); and (4) types of outcome measures [36].

\section{Methodological Quality}

The quality assessment of the selected papers was conducted using the Joanna Briggs Institute's critical appraisal tools for quantitative, qualitative, and mixed methods studies [37]. Studies were not excluded based on their quality assessment as 
we wanted to provide an overview of the available information and its extent.

\section{Data Synthesis}

The results are summarized using descriptive narrative synthesis. All data on LLs were integrated into a table.

\section{Results}

\section{Search Strategy}

Our strategy of searching bibliographic databases retrieved 5609 articles after eliminating duplicates. On the basis of their titles and abstracts, 58 articles were retained as potentially eligible, and their entire texts were evaluated. A total of 12 studies satisfied the selection criteria and were included (Figure 1 [38]).

Figure 1. Flow diagram summarizing the results of the search strategy based on the PRISMA (Preferred Reporting Items for Systematic Reviews and Meta-analyses) recommendations [38].

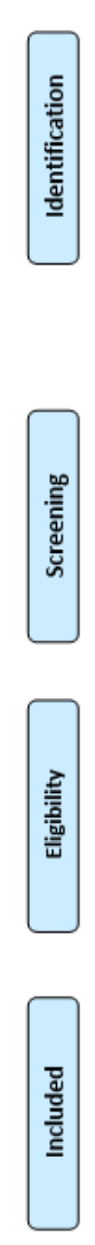

\section{Characteristics of Studies and Participants}

The 12 included studies were conducted in Canada, France, and the Netherlands and were published between 2009 and 2020 (Tables 1-3; Multimedia Appendix 2 [39-50]). These included
4 case studies, 3 mixed methods studies, 3 qualitative studies, 1 quasi-experimental study, and 1 quantitative, iterative pilot usability study. All these studies presented an innovative product to assist older adults with cognitive disorders or dementia. 
Table 1. Characteristics of the included study from the Médéric Alzheimer Foundation living lab in France.

\begin{tabular}{|c|c|c|c|c|c|c|}
\hline Study & Product & Design & Setting and sample & Method & Results & $\begin{array}{l}\text { Quality of life; inde- } \\
\text { pendence; caregivers }\end{array}$ \\
\hline $\begin{array}{l}\text { Charras } \\
\text { et al [44] }\end{array}$ & $\begin{array}{l}\text { "Dance intervention": } \\
\text { a modern and classical } \\
\text { dance teacher with a } \\
\text { nursing background } \\
\text { led a } 50 \text {-minute dance } \\
\text { intervention }\end{array}$ & $\begin{array}{l}\text { Mixed } \\
\text { methods } \\
\text { study }\end{array}$ & $\begin{array}{l}\text { Day-care cen- } \\
\text { ter: } \\
\bullet \quad \mathrm{n}=23 \text { old- } \\
\text { er adults } \\
\text { with } \\
\text { Alzheimer } \\
\text { disease } \\
(12 \text { wom- } \\
\text { en and } 11 \\
\text { men) } \\
\text { Mean age } \\
\text { 83.47 (SD } \\
\text { 5.4) years }\end{array}$ & $\begin{array}{l}\text { Q Quantitative data: } \\
\text { - Get-Up and Go } \\
\text { test; Stop Walk- } \\
\text { ing when Talking } \\
\text { test; one-leg bal- } \\
\text { ance test } \\
\text { Balance Confi- } \\
\text { dence Scale } \\
\text { Quality of Life in } \\
\text { Alzheimer Dis- } \\
\text { ease } \\
\text { Well-being: partic- } \\
\text { ipant's feedback } \\
\text { Q } \\
\text { Qualitative data: verbal- } \\
\text { ization, behaviors, and } \\
\text { attitudes noted in a } \\
\text { logbook }\end{array}$ & $\begin{array}{l}\text { Immediately enhanced } \\
\text { well-being of } 86 \% \text { of } \\
\text { participants, shorter ex- } \\
\text { ecution time in the Get- } \\
\text { Up and Go test for } 66 \% \\
\text { of participants, varia- } \\
\text { tions in participants' } \\
\text { social behaviors }\end{array}$ & $\begin{array}{l}\text { Strengthened physi- } \\
\text { cal condition and } \\
\text { well-being }\end{array}$ \\
\hline
\end{tabular}


Table 2. Characteristics of the included studies from the Innovate Dementia living labs in four regions of northwest Europe (Belgium, Germany, the Netherlands, and the United Kingdom).

\begin{tabular}{|c|c|c|c|c|c|c|}
\hline Study & Product & Design & Setting and sample & Method & Results & $\begin{array}{l}\text { Quality of life; inde- } \\
\text { pendence; caregivers }\end{array}$ \\
\hline $\begin{array}{l}\text { Brankaert } \\
\text { and den } \\
\text { Ouden [45] }\end{array}$ & $\begin{array}{l}\text { "Qwiek Play": a } \\
\text { media system } \\
\text { that creates an } \\
\text { ambient experi- } \\
\text { ence through vi- } \\
\text { sual projection } \\
\text { and sounds }\end{array}$ & $\begin{array}{l}\text { Case } \\
\text { study }\end{array}$ & $\begin{array}{l}\text { Long-term care } \\
\text { units: } \\
\text { - } \quad \text { Study 1: } \\
\text { n=14 resi- } \\
\text { dents with } \\
\text { advanced de- } \\
\text { mentia; } \mathrm{n}=6 \\
\text { care staff in } \\
\text { care home } \\
\text { for } 29 \text { days } \\
\text { Study } 2 \text { : } \\
\text { n=11 resi- } \\
\text { dents with } \\
\text { advanced de- } \\
\text { mentia; } \mathrm{n}=4 \\
\text { care staff in a } \\
\text { care home } \\
\text { for } 33 \text { days } \\
\text { Study } 3: \\
\text { n=28 resi- } \\
\text { dents with } \\
\text { moderate de- } \\
\text { mentia; } \mathrm{n}=3 \\
\text { care staff in } \\
\text { day-care cen- } \\
\text { ter for } 35 \\
\text { days }\end{array}$ & $\begin{array}{l}\text { Sequence of activi- } \\
\text { ties: } \\
\text { - } \quad \text { System and } \\
\text { research } \\
\text { method ex- } \\
\text { plained to } \\
\text { staff } \\
\text { Staff mem- } \\
\text { bers invited } \\
\text { to use and ex- } \\
\text { periment } \\
\text { with the sys- } \\
\text { tem during } \\
\text { the study peri- } \\
\text { od and record } \\
\text { their experi- } \\
\text { ence on an } \\
\text { evaluation } \\
\text { form } \\
\text { After the } \\
\text { study period, } \\
\text { additional in- } \\
\text { sights collect- } \\
\text { ed during the } \\
\text { focus group } \\
\text { discussions } \\
\text { with care } \\
\text { professionals }\end{array}$ & $\begin{array}{l}\text { The system had a } \\
\text { considerable poten- } \\
\text { tial for people } \\
\text { with dementia: } \\
\text { could reduce need } \\
\text { for medication and } \\
\text { could help with } \\
\text { better sleep. The } \\
\text { system increased } \\
\text { the efficiency of } \\
\text { care provision by } \\
\text { giving nurses } \\
\text { more time to en- } \\
\text { gage in care prac- } \\
\text { tices. }\end{array}$ & $\begin{array}{l}\text { Reduction of agi- } \\
\text { tation and aggres- } \\
\text { sion } \\
\text { Improvement of } \\
\text { quality of care } \\
\text { and reduction of } \\
\text { burden on formal } \\
\text { caregivers }\end{array}$ \\
\hline
\end{tabular}




\begin{tabular}{|c|c|c|c|c|c|c|}
\hline Study & Product & Design & Setting and sample & Method & Results & $\begin{array}{l}\text { Quality of life; inde- } \\
\text { pendence; caregivers }\end{array}$ \\
\hline $\begin{array}{l}\text { Brankaert et } \\
\text { al [47] }\end{array}$ & $\begin{array}{l}\text {-GoLivePhone": } \\
\text { smartphone app } \\
\text { for communica- } \\
\text { tion, personal } \\
\text { navigation, and } \\
\text { sending out an } \\
\text { emergency sig- } \\
\text { nal to caregivers }\end{array}$ & $\begin{array}{l}\text { Qualita- } \\
\text { tive } \\
\text { study }\end{array}$ & $\begin{array}{l}\text { Community: } \mathrm{n}=10 \\
\text { older adults with } \\
\text { dementia and their } \\
\text { informal care- } \\
\text { givers }\end{array}$ & $\begin{array}{l}3 \text { home visits over } \\
3 \text { weeks } \\
\text { - } \quad \text { GPS data: ac- } \\
\text { tivity levels } \\
\text { data to see } \\
\text { how often the } \\
\text { phone was } \\
\text { used } \\
\text { Question- } \\
\text { naire: evalu- } \\
\text { ate experi- } \\
\text { ences and } \\
\text { perspectives } \\
\text { of partici- } \\
\text { pants or care- } \\
\text { givers } \\
\text { Reflection } \\
\text { sessions: on } \\
\text { technology } \\
\text { and study }\end{array}$ & $\begin{array}{ll}\text { - } & \text { Device data: } \\
\text { phones were used } \\
\text { very irregularly } \\
\text { Questionnaire: } \\
\text { half of participants } \\
\text { had positive expe- } \\
\text { riences } \\
\text { Reflection session: } \\
\text { most comments } \\
\text { pertained to posi- } \\
\text { tive experiences; } \\
\text { some difficulties } \\
\text { related to techno- } \\
\text { logical errors }\end{array}$ & 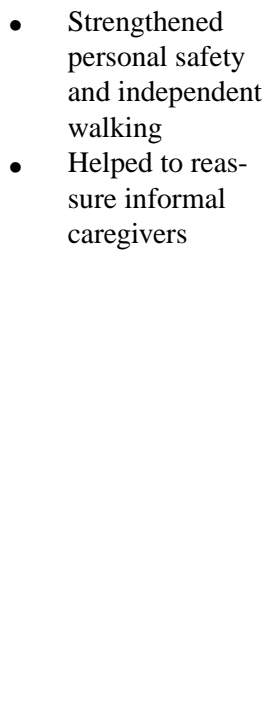 \\
\hline $\begin{array}{l}\text { Brankaert } \\
\text { and den } \\
\text { Ouden, [48] }\end{array}$ & $\begin{array}{l}\text { "PhysiCAL": ac- } \\
\text { tivity reminder } \\
\text { calendar to im- } \\
\text { prove day's } \\
\text { structure and in- } \\
\text { dependence }\end{array}$ & $\begin{array}{l}\text { Case } \\
\text { study }\end{array}$ & $\begin{array}{l}\text { Community: } \mathrm{n}=4 \\
\text { couples ( } 1 \text { older } \\
\text { adult with demen- } \\
\text { tia and } 1 \text { informal } \\
\text { caregiver) }\end{array}$ & $\begin{array}{l}\text { - For } 1 \text { week, } 4 \text { cou- } \\
\text { ples used Physi- } \\
\text { CAL at home. } \\
\text { Perceptions collect- } \\
\text { ed through inter- } \\
\text { views }\end{array}$ & $\begin{array}{l}\text { All the older } \\
\text { adults with demen- } \\
\text { tia said they did } \\
\text { not need the de- } \\
\text { vice, but half of } \\
\text { the caregivers not- } \\
\text { ed that it was } \\
\text { valuable }\end{array}$ & $\begin{array}{l}\text { - } \\
\text { indimulation of } \\
\text { - } \quad \text { Reduction of in- } \\
\text { formal caregiv- } \\
\text { er's burden }\end{array}$ \\
\hline
\end{tabular}


Table 3. Characteristics of the included studies from DOMUS (Laboratoire de Domotique et informatique Mobile à l'Université de Sherbrooke) in Canada.

\begin{tabular}{|c|c|c|c|c|c|c|}
\hline Study & Product & Design & Setting and sample & Method & Results & $\begin{array}{l}\text { Quality of life; indepen- } \\
\text { dence; caregivers }\end{array}$ \\
\hline $\begin{array}{l}\text { Imbeault et } \\
\text { al [49] }\end{array}$ & $\begin{array}{l}\text { "AP@LZ": } \\
\text { electronic orga- } \\
\text { nizer to support } \\
\text { day-to-day activ- } \\
\text { ities and help } \\
\text { people to com- } \\
\text { pensate for } \\
\text { memory prob- } \\
\text { lems }\end{array}$ & $\begin{array}{l}\text { Quasi- } \\
\text { experi- } \\
\text { mental } \\
\text { study }\end{array}$ & $\begin{array}{l}\text { Community: } 3 \text { older } \\
\text { adults with } \\
\text { Alzheimer disease } \\
\text { (aged } 71 \text { years, } 58 \\
\text { years, and } 78 \text { years) }\end{array}$ & $\begin{array}{l}\text { Measures at } 0,3,6, \\
\text { and } 12 \text { months } \\
\text { Impact on daily } \\
\text { living: Multifac- } \\
\text { torial Memory } \\
\text { Questionnaire } \\
\text { and Prospective } \\
\text { and Retrospec- } \\
\text { tive Memory } \\
\text { Questionnaire; } \\
\text { personalized ob- } \\
\text { servation jour- } \\
\text { nals } \\
\text { Impact on psy- } \\
\text { chological com- } \\
\text { ponents: Geri- } \\
\text { atric Depression } \\
\text { Scale and Care- } \\
\text { giver Burden In- } \\
\text { ventory }\end{array}$ & $\begin{array}{l}\text { Postintervention: partic- } \\
\text { ipants continued to use } \\
\text { the system for manag- } \\
\text { ing appointments and } \\
\text { making phone calls. } \\
\text { Depressive symptoms } \\
\text { did not significantly } \\
\text { change in intensity. } \\
\text { Decrease in perceived } \\
\text { caregiver burden ob- } \\
\text { served for one partici- } \\
\text { pant }\end{array}$ & $\begin{array}{l}\text { - Stimulated indepen- } \\
\text { dence } \\
\text { - } \quad \text { Reduced informal } \\
\text { caregiver's burden }\end{array}$ \\
\hline $\begin{array}{l}\text { Bier et al } \\
{[50]}\end{array}$ & $\begin{array}{l}\text { "SemAssist": a } \\
\text { computer pro- } \\
\text { gram to assist } \\
\text { people with se- } \\
\text { mantic aphasia } \\
\text { perform differ- } \\
\text { ent steps of an } \\
\text { activity }\end{array}$ & $\begin{array}{l}\text { Case } \\
\text { study }\end{array}$ & $\begin{array}{l}\text { Community: one } 68 \text { - } \\
\text { year-old woman } \\
\text { with semantic de- } \\
\text { mentia }\end{array}$ & $\begin{array}{l}\text { Therapy comprised } \\
\text { preparing a target } \\
\text { recipe. The partici- } \\
\text { pant was asked to } \\
\text { generate semantic at- } \\
\text { tributes of ingredients } \\
\text { found in one target, } \\
\text { one control, and two } \\
\text { no-therapy recipes. } \\
\text { The study took place } \\
\text { over a 1-year period }\end{array}$ & $\begin{array}{l}\text { Generated semantic at- } \\
\text { tributes of ingredients } \\
\text { pertaining to the target, } \\
\text { and control recipes in- } \\
\text { creased significantly } \\
(P<.001) \text { as compared } \\
\text { with no-therapy recipes } \\
(P=.79) \text {. The propor- } \\
\text { tion of cooked meals } \\
\text { was increased signifi- } \\
\text { cantly }(P=.02)\end{array}$ & $\begin{array}{l}\text { - Stimulated indepen- } \\
\text { dence }\end{array}$ \\
\hline
\end{tabular}

Of the 147 older adults who participated in these studies, 28 (19\%) presented with mild cognitive impairment (MCI), 39 (26.5\%) had Alzheimer disease, 12 (8.2\%) presented with early-stage dementia, $42(28.6 \%)$ presented with moderate dementia, $25(17 \%)$ presented with advanced dementia, and 1 $(0.7 \%)$ presented with semantic dementia. The participants' ages ranged from 66 to 96 years. All studies included men and women. There were eight studies that were conducted in community settings, three in LTHFs, and one in a day-care center. Finally, 27 family caregivers - the partners of older adults affected by cognitive disorders or dementia-and 13 health care professionals were also included in these studies.

\section{Methodological Quality of the Studies}

Measured using the Joanna Briggs Institute's critical appraisal tools, the overall methodological quality of the studies included in this review was poor to moderate [37]. Only the study by Bier et al [50] was evaluated as having high methodological quality (Table 4). 
Table 4. Critical appraisal results for included studies using the Joanna Briggs Institute's Critical Appraisal Checklists.

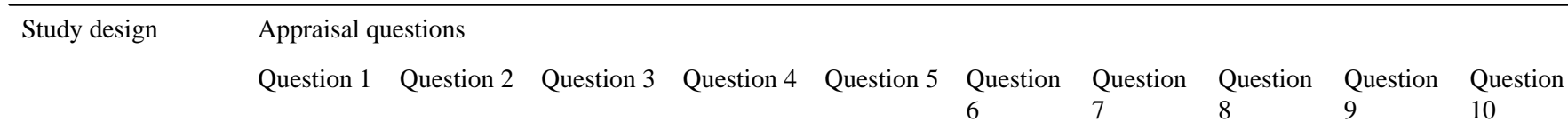

\section{Mixed methods study}

Quantitative analysis ${ }^{\mathrm{a}}$

$\begin{array}{lllllllll}\begin{array}{l}\text { Charras et } \\ \text { al }[44]\end{array} & \text { Yes } & \text { Yes } & \text { Yes } & \text { Yes } & \text { No } & \text { No } & \text { Yes } & \text { Yes } \\ \begin{array}{l}\text { Wu et al } \\ {[39]}\end{array} & \text { Unclear } & \text { Yes } & \text { Yes } & \text { Yes } & \text { No } & \text { No } & \text { Yes } & \text { Yes } \\ \text { de } & \text { Yes } & \text { Unclear } & \text { Yes } & \text { Yes } & \text { No } & \text { No } & \text { Yes } & \text { Yes }\end{array}$

Sant'Anna

et al [43]

\section{Qualitative analysis ${ }^{\mathrm{c}}$}

$\begin{array}{lcccccccccc}\begin{array}{l}\text { Charras et } \\ \text { al [44] }\end{array} & \text { N/A } & \text { Yes } & \text { Yes } & \text { Yes } & \text { Yes } & \text { No } & \text { No } & \text { No } & \text { Yes } & \text { Unclear } \\ \begin{array}{l}\text { Wu et al } \\ {[39]}\end{array} & \text { N/A } & \text { Yes } & \text { Yes } & \text { Yes } & \text { Yes } & \text { No } & \text { No } & \text { Yes } & \text { Yes } & \text { Yes }\end{array}$

de N/A Unclear Unclear Unclear No No No No No

Sant'Anna

et al [43]

\section{Quasi-experimental study ${ }^{\mathrm{e}}$}

Imbeault et al Yes

[49]

Yes

No

Yes

Yes

Yes

Yes

Yes

Quantitative study

Boulay et al No

[42]

Yes Yes

Unclear No

No

Unclear

Unclear

Qualitative study ${ }^{\mathrm{g}}$

Suijkerbuijk et N/A

al [46]

Brankaert et al N/A

[47]

Wu et al [40] N/A

Yes

Yes

Yes

Yes

No

No

Yes

No

Unclear

Yes $\quad$ Yes

No

No

Yes

No

Unclear

Case study ${ }^{\text {h }}$

Brankaert an

den Ouden [45]

Unclear

No

Unclear

Yes

Yes

Brankaert and No

No

No

Yes

N/A Yes

den Ouden [48]

Yes Yes

Yes Yes

Yes Yes

Unclear Yes

N/A Yes

[41]

a Joanna Briggs Institute's Critical Appraisal Checklist for analytical cross-sectional studies [37].

${ }^{\mathrm{b}} \mathrm{No}$ appraisal question.

'Joanna Briggs Institute's Critical Appraisal Checklist for qualitative research [37].

${ }^{\mathrm{d}} \mathrm{N} / \mathrm{A}$ : not applicable.

'Joanna Briggs Institute's Critical Appraisal Checklist for quasi-experimental studies [37].

fJoanna Briggs Institute's Critical Appraisal Checklist for analytical cross-sectional studies [37].

gJoanna Briggs Institute's Critical Appraisal Checklist for qualitative research [37].

hJoanna Briggs Institute's Critical Appraisal Checklist for case reports [37]. 


\section{Description of the Included Studies}

The studies included in our evaluation were conducted in four LLs playing pivotal roles in developing innovations aimed at older adults with MCI or dementia and at their family or professional caregivers. These projects all aimed to contribute to optimizing the health, quality of life, independence, home care, and safety of older adults with MCI or dementia and to support their family and professional caregivers or reduce their burdens (Tables 1-3; Multimedia Appendix 2).

The LUSAGE (Laboratoire d'analyse des Usages en Gerontechnologies) LL, affiliated with the Geriatrics Department of the Broca Hospital and Paris Descartes University in France, specializes in the design, development, and supply of products and services providing assistive technologies to older adults with cognitive impairment (eg, MCI, Alzheimer disease, and related dementias) as well as their family and professional caregivers (Multimedia Appendix 2) [51]. LUSAGE is a partner laboratory of the National Expert Center in Cognitive Stimulation, launched by the National Solidarity Fund for Autonomy, whose main objective is to promote the development and use of innovative cognitive interventions. The European Network of Living Labs (ENoLL) certified LUSAGE in 2012, which has a flexible architectural configuration that can be adapted to conduct in situ observations (eg, home-like settings) according to each project's requirements. LUSAGE develops solutions in assistive technologies in collaboration with their primary end users and stakeholders, which represents a multidisciplinary team comprising specialists from numerous fields such as researchers in geriatrics, technology, cognitive sciences, public health, law, and ethics, in addition to psychologists, physicians, engineers, designers, sociologists, and health economists. LUSAGE's primary end users are older adults with cognitive disorders (recruited from the Broca Memory Clinic, Centers for Local Information and Coordination, and local Alzheimer associations), healthy older individuals, their families, and their informal and professional caregivers. These end users are involved in every stage of the product development cycle (eg, needs gathering, usability testing, monitoring studies, evaluation of technology acceptance, and ethical issues) [51].

One of LUSAGE's primary activities is to test the utility and acceptability of personal assistance robots in older adults' everyday lives (Multimedia Appendix 2). In 2014, Wu et al [39] simulated participants' homes and compared how using the Kompai robot (Kompaï Robotics, Robosoft) to complete daily tasks affected the lives of 6 older adults with MCI and 5 others in good cognitive health. Participants with MCI were able to use Kompai just as well as those with good cognitive health. However, despite the robot's positive attributes, such as its ease of use and playful dimension, participants reported that they had no intention of using a personal assistance robot in their daily life as they had negative perceptions about this type of device, associated with negative representations of dependence linked to aging [39]. With the aim of improving the acceptability of personal assistance robots for the homes of older adults with MCI, LUSAGE subsequently ran the Robadom project [40]. The objective of Robadom was to define an ideal robot, in appearance and functionality, that would meet the expectations of older adults with MCI. The most appreciated functions were cognitive stimulation, object finding, and diary reminders about upcoming events, such as the need to take medication or go to an appointment. Most of the participants had negative perceptions of robots with human characteristics and preferred short robots with stylized, rounded, discrete, and yet familiar shapes [40].

Another innovation developed by LUSAGE was using GPS to improve the independence, quality of life, and safety of home-dwelling older adults with dementia and to help their family caregivers [41]. A mobile telephone attached to the older adult's belt provided standard telephone functionalities, but it also transmitted geolocation data to the family caregiver by SMS text messages and could send numerous alarms. Faucounau et al [41] tested this device for a month in the daily life of an 84-year-old man with Alzheimer disease and his wife. The couple's general impressions were that the device was too bulky, sometimes gave imprecise location coordinates, and had a poor battery life [41].

Finally, LUSAGE has also been used to develop and test innovations in LTHF settings [42,43]. In 2011, Boulay et al [42] tested their MINWii device with 7 older adults with Alzheimer disease institutionalized in a nursing home. MINWii mixes music therapy and cognitive stimulation by allowing players to improvise or play songs of their choice by pointing at a virtual keyboard with a Wii remote control. Numerous benefits of the MINWii, such as positive stimulation of cognitive function, participants' ability to reminisce, and easier interactions with the care team, have been reported [42]. Sant' Anna et al [43] evaluated the impact of using a seal-shaped robot named Paro on the capacity to communicate and the behaviors of 5 nursing home residents with severe Alzheimer disease. Quantitative results indicated that using Paro led to a significant reduction in disturbed behaviors $(P=.04)$, especially anxiety, aggressivity, irritability, and sleep disorders. A positive change in communication skills and abilities was also noted in 4 of the 5 patients. Thus, Paro seemed to be an excellent facilitator of communication for older adults with Alzheimer disease, inciting verbal and tactile communication as well as the expression and transfer of feelings by voice and touch [43].

A second French LL working on projects aimed at older adults with dementia was set up in Versailles in 2017 by the Médéric Alzheimer Foundation (Table 1). It focuses on developing and evaluating innovative responses in this field to improve the integration and quality of life of older adults with Alzheimer disease or related illnesses [52]. This LL collaborates in a coparticipative manner with older adults and their family caregivers, treating them as both actors and experts in their disease. It also works with health care professionals, researchers, and entrepreneurs. The central focus of the Foundation's LL is evaluating the impact of various psychosocial interventions, such as cognitive stimulation, art therapy, music therapy, or reminiscence, on the quality of life of older adults with Alzheimer disease.

In 2020, Charras et al [44] evaluated the impact of a dance therapy intervention on 23 older adults with Alzheimer disease who regularly attended a day-care center. The study's results 
revealed that $86 \%$ of participants $(P<.001)$ experienced a significant increase in well-being immediately after a dance session, and $66 \%$ of them $(P=.04)$ also showed a tendency toward faster times in a balance test [44].

A third European grouping of LLs focuses on developing innovative solutions for older adults with dementia. The Innovate Dementia Project comprises ten partners in four regions of Northwestern Europe (Belgium, Germany, the Netherlands, and the United Kingdom), and they collaborate via more than 25 LLs to explore, develop, test, and evaluate innovative, sustainable solutions that consider the socioeconomic challenges linked to aging and dementia (Table 2) [53]. Their goal is to improve the quality of life and independence of older adults with dementia and to facilitate the support given to them by their close family caregivers. This project began in 2012 and became a member of the ENoLL network in 2014, concentrating on four issues: intelligent lighting systems, nutrition and physical exercise, living environments, and models of assistance. The Innovate Dementia Project allows end users (persons living with dementia and their family caregivers), whose role is central, to collaborate with different stakeholders (care professionals, businesses, academic and knowledge institutes, and local governments) to develop and test innovative products in real-life conditions, notably in the homes of older adults with dementia. To date, this project has involved 500 end users, more than 200 health care professionals, and more than 25 business partners, and these partnerships have allowed them to bring more than 15 innovative solutions to the market.

In 2013, Brankaert and den Ouden [48] presented the results of the first product to be tested at the Eindhoven LL: PhysiCAL, a personal activity reminder calendar that promotes older adults' independence. All of the participating older adults with dementia stated that they did not need such a device, whereas 3 of the 4 family caregivers thought that it had helped [48]. In 2014, Brankaert et al [47] trialed a second product, GoLivePhone, in the homes of 10 older adults with dementia and their family caregivers. The phone had three main functions: communicating with other people, providing support when out in the community via a personal navigation system, and sending an emergency signal to a family caregiver. Family caregivers were able to monitor and consult their partners' smartphones via a web-based app, GoLiveAssist. Although the app was used irregularly and several technical errors occurred during the trial period, slightly more than half of the participants reported having had a very positive experience and that the device had been helpful. Family caregivers reported that they were reassured by the device as it improved their partner's support and safety [47]. A 2016 study by Suijkerbuijk et al [46], conducted in the homes of 12 couples where one of the pairs had dementia, managed to test two innovative products at the same time: the Aangenaam personal evaluation game and the Vitaallicht dynamic light system. The Aangenaam system enables informal data collection on the daily lives of older adults with dementia, and as it takes the form of a game, it has a minimal risk of disturbing their ADLs. The older adult picks a card from a deck and can answer the question in different ways, by writing in a notebook, by answering orally to make an audio recording, or by taking photographs with the camera provided. The questions explored four categories of data: experiences linked to the ADLs, the participant's social and physical context, their personal objectives and significant life events, and a category adaptable to the product or device being tested. As compared with using a questionnaire on a tablet computer, the findings revealed that the Aangenaam system was better suited and more appreciated by participants; however, thanks to the different potential means of response, it also allowed the researchers to gather more details about their daily lives [46]. The Vitaallicht product, for its part, is a dynamic lighting system that uses blue light to positively influence sleep-wake cycles by suppressing melatonin production during the day. After only 2 weeks of use, this system induced a subjective increase in the quality of the participants' sleep [46]. One of the latest products developed by the Innovate Dementia Project is the Qwiek Play media system, which creates a calming ambient experience in a room by projecting images and sound (a walk through the woods, looking up at a starry sky, visiting a farm, or viewing a custom slideshow of family photos accompanied by music). This product was used in 2017 by Brankaert and den Ouden [45], with 25 patients with severe dementia living in nursing homes and 28 older adults with moderate dementia attending a day-care center. The impressions of the 13 health care professionals were also explored. The results reported very positive perceptions about the product, mentioning its potential for use in nonmedicated interventions to reduce stress and agitation in older adults with moderate to severe dementia, thus giving care staff more time to engage in their care practices [45].

Our scoping review identified a final LL aimed at helping older adults with dementia: DOMUS (Laboratoire de Domotique et informatique Mobile à l'Université de Sherbrooke) in Canada (Table 3) [54]. Set up in 2014, this LL represented the first project of its type in Canada, and it is equipped with a rich, multipurpose infrastructure for the design, implementation, and evaluation of different types of cognitive orthotics. The resulting set of orthotics support a wide variety of ADLs (eg, medication, meal preparation, or budgeting), fostering greater independence at home for people with cognitive impairments (Alzheimer disease, mental retardation, schizophrenia, or traumatic brain injury). DOMUS operates three variants of the LL concept: a smart apartment on its campus that is controlled by a home automation system enabling short-term studies in technology-rich simulated housing; an LL in an alternative housing unit for people with traumatic brain injury, enabling long-term ecological studies in a technology-rich real house; and the LL at home that can be installed in older adults' places of residence (apartments and houses), enabling long-term ecological studies in a mobile, agile-technology environment. From the beginning of each project, developing cognitive orthoses involves implicating end users (older adults with cognitive disorders and people with traumatic brain injury) with other stakeholders (clinical researchers, engineers, health care professionals, gerontologists, occupational therapists, neuropsychologists, and researchers in ergonomics and design) to ensure that assistive technologies are focused on users and fully satisfy their needs [54].

In 2011, Bier et al [50] tested a cognitive assistance product named SemAssist with a 68-year-old woman living alone and 
who had semantic dementia. This device helps people with semantic aphasia in performing different stages of an activity. Findings showed that this therapy, involving following the same targeted recipe several times over a year, helped this woman reduce the number of errors she made while preparing that recipe. The intervention stimulated her memory function as food preparation developed new episodic memories surrounding the following recipes. Thanks to SemAssist, the participant's self-confidence in being able to cook also grew, which encouraged her to do so more often. The proportion of meals that she cooked for herself increased significantly $(P=.02)$ [50]. Finally, in 2018, Imbeault et al [49] tested the AP@LZ smartphone app in the homes of 3 older adults with Alzheimer disease. The goals were to optimize their independence in ADLs by compensating for their memory problems, further supporting family caregivers and alleviating their burdens. The AP@LZ works like a personal assistant or organizer and has five main functions, namely appointment reminders, a personal database, a medical database, a list of contacts, and a notepad for jotting down shopping lists. The 3 participants had different profiles with respect to age, cognitive status, and social status. Participant 1 was a 71-year-old married man diagnosed with Alzheimer disease 1 year earlier, who had language problems and both verbal and visual memory deficits. Participant 2 was a 58-year-old married man diagnosed with atypical Alzheimer disease 1 year earlier, dominated by dysexecutive syndrome and constructive and ideomotor apraxia. Participant 3 was a 78-year-old single woman living alone in sheltered housing and diagnosed with Alzheimer disease 1 year earlier, which mainly manifested a memory disorder. The findings underlined that all 3 participants, despite their different profiles, could use the app in their everyday lives. Indeed, they all continued to use it after the study ended as they found that the system helped them, and they especially appreciated the appointment reminder function. Using AP@LZ also reduced the burden on family caregivers. The authors concluded that the app might have long-term utility, despite Alzheimer disease being a progressive disease and that it could be used by people with different profiles and degrees of cognitive impairment [49].

\section{Discussion}

\section{Principal Findings}

This review aimed to identify publications examining all types of LL activities, exploring the needs and expectations of older adults with dementia and looking for solutions, whether they were living in the community or in LTHFs. We discovered 12 studies that met our inclusion criteria (quantitative, qualitative, or mixed methods) involving 147 older adults with MCI or dementia, 27 informal caregivers, and 13 formal caregivers. These studies originated from three European LLs and one Canadian LL playing key roles in research in this field. Their work has allowed the development, testing, and evaluation of a series of innovative products aimed not only at optimizing the health, quality of life, independence, home care, and safety of older adults with MCI or dementia but also at supporting formal and informal caregivers and reducing their levels of burden. Most of the studies in this scoping review reported promising findings, and the LL approach highlighted both positive and negative points in all the devices, products, and services, which will be open to improvements through future testing.

\section{Limitations}

This scoping review has some limitations. Our literature search strategy may have omitted some studies as they did not meet all our inclusion criteria or as researchers failed to identify them in the study selection process. Some bias might have also been present in the reporting of findings by the investigators in the analysis of the selected studies. It is impossible to exclude some bias in the selection of studies as all the included studies had very limited sample sizes. Indeed, only one of the studies was evaluated as having a high methodological quality. The limited number of participants and the overrepresentation of European LLs means that generalizing these findings to a broader population or other countries should be done with great care. Finally, the limited number of recent studies revealed by this scoping review raises questions about whether any LL activities are ongoing and whether LLs are sustainable.

To the best of our knowledge, there are no previous, clear overviews of the research conducted by LLs with respect to older adults with cognitive impairment or dementia. Our scoping review has allowed us to understand the services, research, and clinical activities developed in different LL settings for older adults with dementia. Therefore, it provides valuable information to nurses, general practitioners, policy makers, and other stakeholders involved in LLs dedicated to older adults. Furthermore, the diversity of the research projects that we included managed to test the innovative solutions using a variety of methodologies.

\section{Comparison With Previous Work}

LLs represent a promising approach for developing innovative solutions to the numerous challenges of an increasingly older population [3]. Indeed, it can offer an ideal, pragmatic framework for research involving a realistic, real-life setting, multiple stakeholder participation, multi-method approaches, and cocreation [55].

To the best of our knowledge, there are no best practices for design-driven LLs. The lack of consensus on the practices, methods, tools, and boundaries of LLs raises several obstacles to the adoption of this approach as well as creating confusion about the definition and components of an LL [56]. Thus, some research groups claim to be using an LL approach, although they really are not. In contrast, some research groups using LL approaches are not labeled as such. For example, the ENoLL label is so new that it has not yet been classified as an LL [15]. Furthermore, the complexity and diversity of what is going on within an LL can blur the boundaries among research, industry, and other economic market sectors [15]. Multifactorial difficulties in finding financing for LLs are another frequently reported problem (instability over the medium to long term, problems balancing representativity between stakeholders in decision-making, and investors' different expectations with regard to returns on investment, and the absence of social capital). Managing intellectual property is also problematic because of the lack of a consensus model for doing this and the ad hoc nature of contractual dealings and agreements $[15,56]$. 
Finally, several difficulties have been reported concerning the sustainability of LLs [57]. Primarily because of the notable lack of sustainable financing or nondiversified financing (whether from private or public sources), it is common for LLs not to survive beyond the time needed to conduct their first financed research project [57]. Thus, it seems essential that to have sustainable LLs, they should be developed within solid, dynamic, long-term, strategic frameworks that continuously evaluate financing, new target audiences, and potential revenue streams. They should involve multiple stakeholders and have the capacity to evolve over time, moving from one innovation category to another [57].

With regard to projects aimed at older adults, numerous studies conducted in LLs aim to find solutions to the pressing problems facing older populations in general [26]. However, there are still few innovative tools, solutions, or technologies that are especially adapted for older adults with dementia [25]. It will be essential to promote more research and experiments in LLs aimed at populations with dementia as these approaches are promising and encourage the cocreation of innovative solutions to maintain or improve their health, quality of life, and independence $[58,59]$. Although integrating older adults with dementia into the LL process-from product design to evaluation-is also essential, it remains sporadic, unfortunately, because of the inherent difficulties of collaborating with individuals with an impaired cognitive function and the ethical issues that this raises [29]. LL approaches too often only include formal and informal caregivers when older adults are still capable of participating, and innovative solutions will never be optimally effective if they fail to fully meet their needs and expectations [29]. Several studies have reported that older adults with dementia would be happy to actively participate in the development processes seeking innovative solutions that would benefit them in the future. They are enthusiastic about the idea of contributing to these solutions by bringing their unique and precious experiential knowledge [60]. The LL approach represents an ideal research and experimental framework for older adults with dementia as studies that fail to include them as coparticipants will not be able to meet their real-world needs and reliably show the effects of innovative solutions on this population's daily lives [29]. There are numerous strategies to ensure the voluntary participation of older adults with dementia and overcome the challenges of cognitive impairments and ethics, such as the concepts of fluctuating consent, process consent, or rolling consent. These strategies promote effective communication between all stakeholders involved so that the vulnerable person's willingness to participate can be monitored continuously [61]. A complete LL approach must necessarily involve formal and informal caregivers as innovative solutions must meet the needs and expectations of end users and those who look after them [54]. The LL approach also requires the points of view, expertise, and collaborations of all the involved stakeholders (eg, students, academic institutions, private companies, health care organizations, and patient representative bodies) [62]. Given that most LLs focusing on older adults with dementia appear to be in Europe, this approach requires development on other continents [63]. We do not know of any best practices for design-driven LLs, and it may be necessary to develop guidelines on the LL approach to direct and support the establishment and sustainability of innovative solutions, and to facilitate relationships and engagement with stakeholders and end users [45].

\section{Conclusions}

To the best of our knowledge, there are no clear views of the research conducted by LLs with respect to older adults with cognitive impairments or dementia. This scoping review enabled us to draw together the few but varied existing research findings and contributed to consolidating knowledge in this field. This allowed us to identify 4 LLs that play a central role in research testing and evaluating innovative products to optimize the health, quality of life, independence, home care, and safety of older adults with dementia, whether they live in their homes or in LTHFs. This research also supports and reduces the burden on formal and informal family caregivers. Furthermore, this scoping review could be used as a reference for anybody interested in using LLs with older adults with cognitive impairments or dementia. It provides valuable information to nurses, general practitioners, policy makers, and other stakeholders involved in LLs dedicated to older adults on the practices, methods, and tools that can be used with older adults with cognitive impairment or dementia. To date, very few studies using the LL approach have focused on older adult populations with dementia, notably because of the difficulties associated with their lower cognitive abilities and the ethical challenges this raises. By allowing older adults with dementia to experience cocreation within a well-defined environment and influence a potential product's design, ease of use, or acceptability, the other stakeholders should be better able to address their needs and expectations. Therefore, it is essential that more LL experiments integrate both older adults with dementia, their formal and informal caregivers, and all other pertinent stakeholders. This will assist in the development of more appropriate, better adapted, sustainable, innovative interventions, services, and products to meet the growing societal challenges brought on by dementia.

\section{Authors' Contributions}

All authors contributed to the design and development of this scoping review and to the drafting of the manuscript, and approved the final version and agreed to be held accountable for all aspects of the work.

\section{Conflicts of Interest}

None declared. 


\section{Multimedia Appendix 1}

Bibliographic database search strategies.

[DOCX File, 24 KB-Multimedia Appendix 1]

\section{Multimedia Appendix 2}

Characteristics of the included studies from the LUSAGE (Laboratoire d'analyse des Usages en Gerontechnologies) living lab in France.

[DOCX File, 26 KB-Multimedia Appendix 2]

\section{References}

1. People in the EU: Who Are We and How Do We Live? Publications Office of the European Union. Eurostat. 2019. URL: https://ec.europa.eu/eurostat/documents/3217494/7089681/KS-04-15-567-EN-N.pdf/8b2459fe-0e4e-4bb7-bca7-7522999c3bfd [accessed 2021-07-28]

2. Global Strategy and Action Plan on Ageing and Health. World-Health-Organization. 2017. URL: https://www.who.int/ ageing/GSAP-Summary-EN.pdf [accessed 2021-07-28]

3. Lapointe D, Guimont D. Open Innovation Practices Adopted by Private Stakeholders: Perspectives for Living Labs. Emerald Group Publishing Limited. 2015. URL: https://www.emerald.com/insight/content/doi/10.1108/info-01-2015-0003/full/html [accessed 2021-07-28]

4. Bächle M, Daurer S, Judt A, Mettler T. Assistive technology for independent living with dementia: Stylized facts and research gaps. Health Pol Technol 2018 Mar;7(1):98-111. [doi: 10.1016/j.hlpt.2017.12.002]

5. Vredenburg K, Isensee S, Righi C. User-Centered Design: An Integrated Approach. Upper Saddle River, NJ: Prentice Hall; 2002.

6. Dell'Era C, Landoni P. Living Lab: A Methodology between User-Centred Design and Participatory Design. Inov Manag 2014 Mar 18;23(2):137-154. [doi: 10.1111/caim.12061]

7. Bergvall-Kareborn B, Hoist M, Stahlbrost A. Concept Design With a Living Lab Approach. In: 42nd Hawaii International Conference on System Sciences. 2009 Presented at: CSS'09; May 17-19, 2009; Hawaii. [doi: 10.1109/hicss.2009.123]

8. Coignard P, Joseph P, Busnel M, Fattal C, Picard R, Laffont I. Living Labs Health and Autonomy: what place for users and clinicians? The example of the French APPROCHE Association. Annals of Physical and Rehabilitation Medicine 2015 Sep;58:e54-e55. [doi: 10.1016/j.rehab.2015.07.134]

9. Sauer S. Faculty of Behavioural, Management and Social Sciences. New York, USA: Universiteit Twente; 2013.

10. Hossain M, Leminen S, Westerlund M. A systematic review of living lab literature. J Clea Produc 2019 Mar;213:976-988 [FREE Full text] [doi: 10.1016/j.jclepro.2018.12.257]

11. Kareborn BB, Stahlbrost A. Living lab: an open and citizen-centric approach for innovation. Int J Innco 2009;1(4):356. [doi: 10.1504/ijird.2009.022727]

12. Bergvall-Kåreborn B, Eriksson C, Ståhlbröst A, Svensson J. A Milieu for Innovation: Defining Living Labs. In: The 2nd Ispim Innovation Symposium: Simulating Recovery - the Role of Innovation Management. In: Huizingh KRE, Conn S, Torkkeli M, Bitran I. editors. ISPIM Innovation Symposium /12/2009 - 09/12/2009; 2009 Presented at: ISPIM'09; December 6-9, 2009; New York. [doi: 10.22215/timreview/951]

13. Schaffers H, Turkama P. Living labs for cross-border systemic innovation. Technol Manag Innov Rev 2012:30. [doi: 10.22215/timreview/605]

14. Følstad A. Living Labs for innovation and development of information and communication technology: a literature review. The Electronic Journal of Virtual Organizations and Networks 2008;10.

15. Picard R, Poilpot L. Pertinence et valeur du concept de «Laboratoire vivant » (Living Lab) en santé et autonomie. Ministère de l'économie des finances et de l'industrie 2011:68-72.

16. Living Labs EN. European Network of Living Labs. BrusselsNoLL. 2019. URL: https://enoll.org/newsroom/ [accessed 2020-12-15]

17. Westerlund M, Leminen S. Managing the challenges of becoming an open innovation companyxperiences from living labs. Technology Innovation Management Review 2011;10:25. [doi: 10.22215/timreview/489]

18. Payne A, Storbacka K, Frow P, Knox S. Co-creating brands: Diagnosing and designing the relationship experience. Journal of Business Research 2009 Mar;62(3):379-389. [doi: 10.1016/j.jbusres.2008.05.013]

19. Almirall E, Wareham J. Living labs and open innovation: Roles and applicability. The Electronic Journal for Virtual Organization and Networks 2008;10(3):46.

20. Cleland B. Innovation of eParticipation strategies using living labs as intermediaries. Electronic Journal of e-Government 2012;10(2):32.

21. Lethin C, Rahm Hallberg I, Renom Guiteras A, Verbeek H, Saks K, Stolt M, et al. Prevalence of dementia diagnoses not otherwise specified in eight European countries: a cross-sectional cohort study. BMC Geriatr 2019 Jun 24;19(1):1-10. [doi: 10.1186/s12877-019-1174-3] 
22. Topo P. Technology Studies to Meet the Needs of People With Dementia and Their Caregivers: A Literature Review. Journal of Applied Gerontology 2008 Oct 01;28(1):5-37. [doi: 10.1177/0733464808324019]

23. Boldy D, Grenade L, Lewin G, Karol E, Burton E. Older people's decisions regarding 'ageing in place': a Western Australian case study. Australas J Ageing 2011 Sep;30(3):136-142. [doi: 10.1111/j.1741-6612.2010.00469.x] [Medline: 21923707]

24. North MS, Fiske ST. Modern Attitudes Toward Older Adults in the Aging World: A Cross-Cultural Meta-Analysis. Psychol Bull 2015 Sep;141(5):993-1021. [doi: 10.1037/a0039469] [Medline: 26191955]

25. Petonito G, Muschert G. Silver Alert: Societal Aging, Dementia, and Framing a Social Problem. Critical Gerontology Comes of Age: Routledge. 2018; 2018:146-162.

26. Meiland F, Innes A, Mountain G, Robinson L, van der Roest H, García-Casal JA, et al. Technologies to Support Community-Dwelling Persons With Dementia: A Position Paper on Issues Regarding Development, Usability, Effectiveness and Cost-Effectiveness, Deployment, and Ethics. JMIR Rehabil Assist Technol 2017 Jan 16;4(1):e1 [FREE Full text] [doi: 10.2196/rehab.6376] [Medline: 28582262]

27. Van der Roest HG, Wenborn J, Pastink C, Dröes RM, Orrell M. Assistive technology for memory support in dementia. Cochrane Database Syst Rev 2017 Dec 11;6:CD009627. [doi: 10.1002/14651858.CD009627.pub2] [Medline: 28602027]

28. Koskinen I, Zimmerman J, Binder T, Redström J, Wensveen S. Design Research Through Practice From the Lab, Field, and Showroom. Waltham, MA: Morgan Kaufmann; 2011.

29. Astell AJ, Ellis MP, Bernardi L, Alm N, Dye R, Gowans G, et al. Using a touch screen computer to support relationships between people with dementia and caregivers. Interacting with Computers 2010 Jul;22(4):267-275. [doi: 10.1016/j.intcom.2010.03.003]

30. Payne A, Ballantyne D, Christopher M. A stakeholder approach to relationship marketing strategy. European Journal of Marketing 2005 Jul;39(7/8):855-871. [doi: 10.1108/03090560510601806]

31. Følstad A. Living Labs for innovation and development of information and communication technology: A literature review. The Electronic Journal of Virtual Organizations and Networks 2008;10(8):131.

32. Leminen S, Westerlund M, Nyström A. Living labs as open-innovation networks. Technology Innovation Management Review 2012;2:11. [doi: 10.22215/timreview/602]

33. Ballon P, Schuurman D. Living labs: concepts, tools and cases. Info 2015;4:11. [doi: 10.1108/info-04-2015-0024]

34. Verloo H, Lorette A, Gomes DRC, Rosselet AJ, Gillès DPE, Matos QA. A Comprehensive Scoping Review Protocol of Using Living Labs to Explore Needs and Solutions for Older Adults with Dementia. Smart Homecare Technology and TeleHealth. URL: https://doi.org/10.2147/SHTT.S233130 [accessed 2020-12-15]

35. Tricco AC, Lillie E, Zarin W, O'Brien KK, Colquhoun H, Levac D, Tunçalp, et al. PRISMA Extension for Scoping Reviews (PRISMA-ScR): Checklist and Explanation. Ann Intern Med 2018 Oct 02;169(7):467-473. [doi: 10.7326/M18-0850] [Medline: $\underline{30178033}$ ]

36. Aguayo-Albasini JL, Flores-Pastor B, Soria-Aledo V. [GRADE system: classification of quality of evidence and strength of recommendation]. Cir Esp 2014 Feb;92(2):82-88 [FREE Full text] [doi: 10.1016/j.ciresp.2013.08.002] [Medline: 24361098]

37. Aromataris E, Munn Z, editors. JBI Manual for Evidence Synthesis. USA: JBI; 2020.

38. Moher D, Liberati A, Tetzlaff J, Altman DG. Preferred reporting items for systematic reviews and meta-analyses: the PRISMA statement. PLoS Med 2009 Jul 21;6(7):e1000097 [FREE Full text] [doi: 10.1371/journal.pmed.1000097] [Medline: 19621072]

39. Wu Y, Wrobel J, Cornuet M, Kerhervé H, Damnée S, Rigaud A. Acceptance of an assistive robot in older adults: a mixed-method study of human-robot interaction over a 1-month period in the Living Lab setting. Clin Interv Aging 2014;9:801-811 [FREE Full text] [doi: 10.2147/CIA.S56435] [Medline: 24855349]

40. Wu Y, Wrobel J, Cristancho-Lacroix V, Kerhervé H, Chetouani M. Le projet Robadom : conception d'un robot d'assistance pour les personnes âgées. Revue de Gériatrie 2013;38(5):349.

41. Faucounau V, Riguet M, Orvoen G, Lacombe A, Rialle V, Extra J, et al. Electronic tracking system and wandering in Alzheimer's disease: a case study. Ann Phys Rehabil Med 2009;52(7-8):579-587 [FREE Full text] [doi: 10.1016/j.rehab.2009.07.034] [Medline: 19744906]

42. Boulay M, Benveniste S, Boespflug S, Jouvelot P, Rigaud A. A pilot usability study of MINWii, a music therapy game for demented patients. Technol Health Care 2011;19(4):233-246. [doi: 10.3233/THC-2011-0628] [Medline: 21849735]

43. de Sant'Anna M, Morat B, Rigaud A. Adaptabilité du robot Paro dans la prise en charge de la maladie d'Alzheimer sévère de patients institutionnalisés. NPG Neurologie - Psychiatrie - Gériatrie 2012 Feb;12(67):43-48. [doi:

10.1016/j.npg.2011.10.002]

44. Charras K, Mabire J, Bouaziz N, Deschamps P, Froget B, de MA. Dance intervention for people with dementia: Lessons learned from a smallsample crossover explorative study. The Arts in Psychotherapy. URL: https://doi.org/10.1016/j.aip. 2020.101676 [accessed 2020-12-15]

45. Brankaert R, den Ouden E. The Design-Driven Living Lab: A New Approach to Exploring Solutions to Complex Societal Challenges. Technology Innovation Management Review;Volume 7, Issue 2017:1. [doi: 10.22215/timreview/1049] 
46. Suijkerbuijk S, Brankaert R, de Kort YAW, Snaphaan LJAE, den Ouden E. Seeing the first-person perspective in dementia : a qualitative personal evaluation game to evaluate assistive technology for people affected by dementia in the home context. Interacting with Computers. URL: https://doi.org/10.1093/iwc/iwu038 [accessed 2020-12-15]

47. Brankaert R, Snaphaan L, den Ouden E. Stay in Touch: An in Context Evaluation of a Smartphone Interface Designed for People with Dementia. Springer, Cham. URL: https://doi.org/10.1007/978-3-319-13105-4 42 [accessed 2020-12-15]

48. Brankaert R, den Ouden E. Setting up a LivingLab for innovation in the dementia care chain, a case study of the PhysiCAL. In: Lappeenranta University of Technology Press. 2013 Presented at: the XXIV ISPIM Conference on Innovating in Global Markets : Challenges for Sustainable Growth; 2013; Lappeenranta University of Technology Press p. 16-19.

49. Imbeault H, Gagnon L, Pigot H, Giroux S, Marcotte N, Cribier-Delande P, et al. Impact of AP@LZ in the daily life of three persons with Alzheimer's disease: long-term use and further exploration of its effectiveness. Neuropsychol Rehabil 2016 Apr 28:1-24. [doi: 10.1080/09602011.2016.1172491] [Medline: 27126266]

50. Bier N, Macoir J, Joubert S, Bottari C, Chayer C, Pigot H, SemAssist Team. Cooking "shrimp à la créole": a pilot study of an ecological rehabilitation in semantic dementia. Neuropsychol Rehabil 2011 Aug;21(4):455-483. [doi: 10.1080/09602011.2011.580614] [Medline: 21714761]

51. Pino M, Benveniste S, Kerhervé H, Rigaud A. Contribution of the Living Lab approach to the development, assessment and provision of assistive technologies for supporting older adults with cognitive disorders. Studia Informatica Universalis 2014:34-62.

52. Le Living Lab 2020. Fondation-Médéric-Alzheimer. URL: https://www.fondation-mederic-alzheimer.org/living-lab [accessed 2020-12-15]

53. Brankaert R, den Ouden E, Brombacher A. Innovate dementia: the development of a living lab protocol to evaluate interventions in context. Emerald Group Publishing Limited;Volume 17 NO. 4 2015:2015. [doi: 10.1108/info-01-2015-0010]

54. Pigot H, Giroux S. Living labs for designing assistive technologies. 2015 Oct 17 Presented at: IEEE 17th International Conference on e-Health Networking, ApplicationsServices (Healthcom); Oct. ; Boston, MA. USA; 2015; Boston p. $14-17$. [doi: 10.1109/healthcom.2015.7454493]

55. Ballon P, Schuurman D. Living labs: concepts, tools and cases. Info 2015;4:11. [doi: 10.1108/info-04-2015-0024]

56. Dubé P, Sarrailh J, Grillet C, Billebaud C, Zingraff V, Kostecki I. Le livre blanc des Living Labs. UMWELT, editor 2014:2014.

57. Mastelic J, Pieter BM, Sahakian M, Bonazzi R. How to keep a living lab alive? Info 2015;17(4):12-25. [doi: 10.1108/info-01-2015-0012]

58. Schuurman D. Bridging the gap between Open and User Innovation: exploring the value of Living Labs as a means to structure user contribution and manage distributed innovation. Ghent: Ghent University; 2015.

59. Leminen S, Nyström A, Westerlund M. A typology of creative consumers in living labs. Journal of Engineering and Technology Management 2015 Jul;37:6-20. [doi: 10.1016/j.jengtecman.2015.08.008]

60. Gove D, Diaz-Ponce A, Georges J, Moniz-Cook E, Mountain G, Chattat R, European Working Group of People with Dementia. Alzheimer Europe's position on involving people with dementia in research through PPI (patient and public involvement). Aging Ment Health 2018 Jun;22(6):723-729. [doi: 10.1080/13607863.2017.1317334] [Medline: 28513210]

61. Novitzky P, Smeaton AF, Chen C, Irving K, Jacquemard T, O'Brolcháin F, et al. A review of contemporary work on the ethics of ambient assisted living technologies for people with dementia. Sci Eng Ethics 2015 Jun;21(3):707-765. [doi: 10.1007/s11948-014-9552-x] [Medline: 24942810]

62. Dutilleul B, Birrer F, Mensink W. Unpacking European Living Labs: Analysing Innovation's Social Dimensions. Central European Journal of Public Policy 2010;4(1):60.

63. Kim J, Kim YL, Jang H, Cho M, Lee M, Kim J, et al. Living labs for health: an integrative literature review. Eur J Public Health 2019 Jun 06:55-63. [doi: 10.1093/eurpub/ckz105] [Medline: 31169898]

\author{
Abbreviations \\ ADL: activities of daily living \\ DOMUS: Laboratoire de Domotique et informatique Mobile à l'Université de Sherbrooke \\ ENoLL: European Network of Living Labs \\ ICT: information and communication technology \\ LL: living lab \\ LTHF: long-term health care facility \\ LUSAGE: Laboratoire d'analyse des Usages en Gerontechnologies \\ MCI: mild cognitive impairment
}


Edited by J Wang; submitted 23.03.21; peer-reviewed by T Dening, I Ahmed, L Robinson; comments to author 29.04.21; revised version received 27.05.21; accepted 01.06.21; published 19.08.21

Please cite as:

Verloo H, Lorette A, Rosselet Amoussou J, Gillès de Pélichy E, Matos Queirós A, von Gunten A, Perruchoud E

Using Living Labs to Explore Needs and Solutions for Older Adults With Dementia: Scoping Review

JMIR Aging 2021;4(3):e29031

URL: https://aging.jmir.org/2021/3/e29031

doi: 10.2196/29031

PMID: $\underline{34420916}$

CHenk Verloo, Adrien Lorette, Joëlle Rosselet Amoussou, Estelle Gillès de Pélichy, Alcina Matos Queirós, Armin von Gunten, Elodie Perruchoud. Originally published in JMIR Aging (https://aging.jmir.org), 19.08.2021. This is an open-access article distributed under the terms of the Creative Commons Attribution License (https://creativecommons.org/licenses/by/4.0/), which permits unrestricted use, distribution, and reproduction in any medium, provided the original work, first published in JMIR Aging, is properly cited. The complete bibliographic information, a link to the original publication on https://aging.jmir.org, as well as this copyright and license information must be included. 